Special Issue on Violence against Individuals and Communities: Reflecting on the Trayvon Martin Case [This article appears in the Narratives and Reflections section of the Special Issue]

\title{
Reflections on the Murder of Trayvon Martin
}

\author{
Reston N. Bell, Tiffany J. Jones, Ricshawn Adkins Roane, Kidist M. Square, \\ and Rita Chi-Ying Chung
}

George Mason University

\begin{abstract}
The tragic murder of 17-year-old Trayvon Martin in Sanford, Florida has quickly become the platform from which an entire movement has emerged. The first four authors, as members of the African American community, have elected to share their own personal experiences, reactions, and struggles with not only racial discrimination as it relates to the Trayvon Martin case, but racial discrimination in general for African Americans. The purpose of the article is to educate readers on the harsh realities of pervasive racism and to provide recommendations on ways it can be addressed. At the conclusion of this article, the authors have provided recommendations for training programs; educators and practitioners that will help them effectively work through instances of racial discrimination.
\end{abstract}

Keywords. racism, African American youth, African Americans, youth, violence

\section{Introduction}

Trayvon Martin was a 17-year-old African American young man who was gunned down by George Zimmerman in Sanford, Florida. The events leading up to and immediately following his murder on February $26^{\text {th }}, 2012$, were, and are still, riddled with controversy. George Zimmerman, a neighborhood watch volunteer turned vigilante, placed a 9-1-1 emergency call to report "a suspicious person" (CNN Wire Staff, March 23, 2012). Though told to discontinue his pursuit, George Zimmerman persisted and an altercation took place between him and Trayvon (CNN Wire Staff, March 23, 2012). To date, many of the details remain uncertain but one fact is 
inarguable, at precisely 7:25 PM, Trayvon Martin was shot and killed by George Zimmerman (CNN Wire Staff, March 23, 2012). While Zimmerman was armed with a gun, Trayvon met Zimmerman with only a cell phone, a bag of skittles, and a can of tea to shield himself.

Tragically, it was not until March 19, 2012, that the Justice Department launched an investigation into Trayvon's death and not until April 11 when George Zimmerman was charged with, and arrested for, second-degree murder (CNN Wire Staff, March 23, 2012). It took almost six weeks and a collective uproar from not only the African American community but also many other groups that rallied with us to see action and justice for Trayvon.

\section{Who We Are and Why We Wrote Our Reflections}

We are four African American women in a graduate counseling program that focuses on multiculturalism, social justice, and advocacy. The fifth author is a faculty member who supported and assisted with the development of the article. It appears to be an easy subject, but it is never easy talking about issues such as race, class, discrimination, inequalities, unfair treatment, and access to resources. This is particularly difficult because an authentic discussion requires courage, as one must first undergo genuine self-exploration. When the murder of Trayvon Martin came to light, it seemed to take a greater toll on the African American students in our program.

We decided to write our reflections because we were compelled to stand up and speak, where others were silent. Despite our different life experiences and our diverse perspectives about the situation, we shared the same anger and outrage. When this writing opportunity presented itself, we had no idea it would have such a major impact. None of us anticipated that it would turn into a heartfelt article that would allow us to so vividly paint our pain. Professional counselors in training are often expected to have a specific tone and are not to draw or speak outside of the lines, but writing this article was cathartic in that it gave us a chance to reveal our humanity and express how we truly felt at that time. We did not write these reflections to get recognized; we wrote them for ourselves and for the people who feel as we do, and even more so for those who do not. We hope this article gives people a chance to see our damaged hearts and provides some insight into the African American experience. Furthermore, we hope that our reflections will motivate our readers to work together in order to eradicate racism and prevent additional situations such as Trayvon's from occurring in the future.

\section{Introducing our Readers to our Emotions}

We have prepared a documentary of what we have experienced since the murder of Trayvon Martin. Unlike newly released movies that have been pre-screened and then rated by a committee, what we have written below has no rating. Though there are some glimmers of hope, much of our account is filled with difficult emotions like anger, frustration, hurt, and sprinkles of helplessness. As the reader or the audience screening this work, you will watch our emotions play out on paper. However, there are no actors and no people reading lines or getting into character; not here. Here, there is no need for us to imagine what we have endured and experienced firsthand. 
While reading this work, there may be times when you, the reader, become angry with the authors because the story does not end the way you expected, you may become frustrated with the other characters that play a major part in the work, or even somewhat saddened because you wish things could have panned out differently. As we take you through our subjective experiences, it is our hope that you will be able to enlighten others. We aspire for the story we project to reach others and prevent further suffering. Though we opted to share some of our deepest felt and most successfully hidden emotions, it is not our intent to offend or lose our readers. Collectively, it is our hope that the words we share below will speak life, provoke change, and amplify the voices of our community. Immediately following our personal reflections, we have highlighted some of the common themes that emerged in our writing.

\section{Personal Reflections}

\section{A Mother's Love - Ricshawn Adkins Roane}

I am an African-American graduate student, a daughter, a sister, a wife, and a mother. These are my reflections on the murder of Trayvon Martin and the initial lack of response by local law enforcement. Junius Stinney $\mathrm{Jr}^{1}$... Emmett Till ${ }^{2}$... Trayvon Martin... I never knew that as an expectant parent I would dream of every aspect of my unborn child's life. I dreamed of whether the child would be a boy or a girl, whose eyes they would have, what they would be like, how they would walk and talk, and what they would be when they grew up. I dreamed of the fame my child might achieve; that one day his or her name (and a part of me) would be immortalized in history for his or her great accomplishments. And in all those dreams, I naively took for granted that my child would live long enough to grow up.

But for the parents of George Junius Stinney, Jr., for the parents of Emmett Till, for the parents of Trayvon Martin, and for the parents of countless other less well-known, but no less wellloved young Black men, theirs were not only dreams deferred, but dreams prematurely snuffed out.

And now, as an African American mother to a four-year-old African American son, the fear that grips me is whether my son, my baby, will be in the wrong place at the wrong time, make the wrong comment to the wrong person, or just appear suspicious to a gun-toting self-proclaimed neighborhood watch captain in a state with a "Stand Your Ground" law (The Florida Legislature, 2012).

My initial reaction to Trayvon Martin's murder and the ensuing lack of response by local law enforcement was anger. Anger at how unremarkable Sanford, Florida authorities thought Trayvon Martin's death would be. From all appearances, they never considered that the public would question their decision to dismiss Trayvon's death as unworthy of further investigation. Is that decision reflective of the value of Black male life in Sanford? Of the police department's

\footnotetext{
${ }^{1}$ George Junius Stinney, Jr. was a 14-year-old African American teen who was executed in 1944 for allegedly murdering two White girls.

${ }^{2}$ Emmet Till was a 14-year-old African American teen who was murdered in 1955 allegedly for flirting with a White woman.
} 
license to operate with impunity? Or, of the powerful gun lobby that helped propel "Stand Your Ground" into legislation? Or perhaps, all of the above.

Mostly, what consumes me now is an aching heart for the parents who lost their son. Until I became a parent, I did not understand that each child has a unique and distinct smell, perhaps imperceptible to a casual observer, but an ever-present personal signature to a parent. Some days I find myself going into my children's bedrooms and holding a pillow or a blanket up to my nose just to smell their essence and remember them anew. I do this knowing that my children are only temporarily absent from me while away at preschool or on an extended play date and that they will return. I wonder how Trayvon's parents cope knowing that he is permanently absent. Have they washed his linens since his death or do they go in at night and stretch out across his bed, hoping to catch a lingering whiff of his scent, only to end up weeping for all that was lost? Do they recall the funny things he said that made him so unique and so remarkable?

As a teenager, I remember questioning one of my cousins who was pregnant with twin boys about whether she was concerned about "bringing two more Black boys into a world that was intent on destroying them." I remember that her and her husband's vague response about doing the best they could and covering the boys in prayer rang hollow and selfish to me back then. Fast forward 20 years and I am amazed at how similar my own response would be today. My husband and I also bought into the myth that if we stressed the importance of education, bought a home in a good neighborhood with good schools, made a point to establish positive relationships with our children's teachers and taught our children to be respectful and kind, we could insulate our children, and particularly our young son, from the reality of life in the United States for African American men; the reality that the cause of death for over half of young black men ages 15 to34 is homicide (Centers for Disease Control, 2004). And then, the murder of Trayvon Martin thrust that reality back into the limelight. African Americans can be articulate, live in a nice neighborhood, go to the right schools, be president of the PTA and still, in an instant, if you are Black, it can all be over.

While I still dream of all the wonderful things my son might do with his life, and have high aspirations for him, I also hope that his name never gets added to the long and bloody list of young Black men gone too soon. George Junius Stinney Jr... Emmett Till...Trayvon Martin... Who's next?

\section{Want to be a white Man for a Day - Tiffany J. Jones}

I will attempt to regain some sense of control within the Black community by capitalizing the " $\mathrm{B}$ " in Black and making the " $\mathrm{w}$ " in white lowercase. Like the child with an eating disorder in a dysfunctional family, I need to establish my sense of control and power within my own life. Typically, when we read empirical articles the reader is informed of the basic demographics of the participants. I will categorize myself for you, the reader, to better understand my viewpoint. I carry the hurt of the Black race at a diverse yet predominantly white university. My master's program has inspired me to challenge the norm, so I present to you the reader, pure unadulterated emotion, which I hope will move you toward social justice. I will illustrate what it means to be a minor citizen, excuse me, a minority in America. I will shed light on what it means for me to be Black in America and how it relates to being a counselor. 
Being Black in America is the fear of the unknown. It is the desire to be a man for a day, 24 hours of complete bliss as a white man. It has to be the most pleasant life to live, akin to royalty. In my experience, it feels as if white men can kill Black boys and rape Black women of their identity and get away with it, deny adequate education to the less fortunate, say things like "I don't see color," and make others believe they are non-racist by saying politically correct things such as "inner-city youth". White men send their children to school without worrying about a teacher unjustly punishing their child. Being a white man appears to be the most pleasant life to live.

Even when I close my eyes, I am still Black and my Black equals "fear me because I am evil". I can only imagine the last seconds of the world through Trayvon's eyes. "I bear my soul screaming help me while carrying an iced tea and bag of candy, but you still see the evil within me. I walk away from you hurriedly to try to find safety but you chase after me. I leave. You run closer. I leave. You confront me. I leave. You kill me."

To me, being Black in America is like being in a desert crawling towards a bottle of water that everyone else has, but I can never attain. The bottle gets dangled in our faces, the perspiration even falls at our fingertips, but it is not enough to quench our thirst from the hard and long road we have traveled. Being Black in America is having the rest of the world tell you that you do not deserve that bottle of water and they would rather see you suffer than to ease your pain. Being Black in America is knowing, without a shadow of a doubt, that you will die never being able to even taste a drop of that water, the thirst quenching drop of white privilege.

I have been mostly angry, angry at the world, white people in particular, after Trayvon's murder. Apparently Trayvon Martin's hoodie killed him. Maybe the strings sewn within his hood sprung up with life and twisted ever so tightly and hanged Trayvon like a noose. It's probably easier to believe that the tea can he was carrying miraculously split open, sliced, his finger and caused him to bleed out. I would probably feel more at ease if he choked on the 1.2 centimeter sized Skittle and died instantly. Sadly, none of these magical events occurred, an inanimate object did not kill him. No, he was murdered by a man carrying a deadly weapon.

I am a Black female student at a predominantly white university attempting to make a change but feeling frustrated that most people do not seem to understand. I will admit, now I have a more renewed sense of commitment to creating a safe haven for my fellow Black people. I hope that I embody a sense of pride that makes them feel comfort where they do not experience it in their everyday lives. Without the majority of white people using their white privilege $^{3}$ to advocate for change and social justice, we are fighting a battle that is highly likely to end in more deaths and we are forced to return home to mothers saying, "we lost another". What do I want from those who possess power? I want them to acknowledge the struggle people of color have to endure. I want them to acknowledge the overarching hand of white privilege and its roots in white supremacy. I want them to acknowledge that just because they don't wear a white sheet does not mean they do not hurt me. I want them to acknowledge that they have permanently impacted the lives of people of color. Nevertheless, we fight with all our power to hold back our emotions and show them that we are strong and will continue to survive in the land we built for their children.

\footnotetext{
${ }^{3}$ McIntosh, Peggy. (1980). White Privilege: Unpacking the invisible knapsack. Independent School.
} 


\section{Raised to Be Small So That Others Might Feel Big - Reston N. Bell}

It has been months since this case first surfaced, weeks since I first decided to write, and days since I first sat before these keys with the intent to sincerely share myself with you, the reader. Silence has never been my strong suit and the responsibility and power that we are permitted through the telling of our stories is not something that I have ever taken lightly. Nevertheless, rather than running to join the masses in protest, up until recently I have been moved to silence, until this moment (10:08 PM on a Friday evening), I have been experiencing what I am conceptualizing as the suspension of my willingness to expend energy digesting, rationalizing, or even labeling what has taken place with this case. Sane men can spend a lifetime trying to make sense of the inner workings of one with a delusional mind and never come to any clear conclusions. I have asked myself, "how is seeking to understand this case any different and why should I embark upon this journey".

The reality is, however heterogeneous and loosely defined the African American community is, the lack of voice that we have been given as a group over the landscape of our country's history is inarguable. Consequently, being afforded the distinct opportunity to speak life into our context while simultaneously giving reverence to not only Trayvon Martin, but the many young African American men that he represents, is a privilege that I most humbly accept. In the following pages, I will share the lens through which I see the world, my emotional response to Trayvon's murder, and why I suspect the community reacted as it did.

I am an African American woman. I am someone's daughter, grandbaby, aunty, friend, confidant, teacher, mentor, counselor, and colleague. Very little is more moving than glancing into the eyes of children and telling them that they can grow up and then go on to be anything. Only one unsolicited appointment has challenged me on deeper levels. To this point, the most powerful and life altering position that I have held is that of being a big sister to my little brother who warmly refers to me as "Sissy." Though it took some time to adjust to and even like the kid, at six years my junior, being a big sister to my little brother, who I affectionately refer to as Ray Ray, has been one of the best yet most frightening lived experiences I have had to date. When I finally let the cold and harsh realities of the Trayvon Martin case wash over me, I wept. I wept because despite my efforts to see Trayvon and shake free from my painful thoughts, in his eyes, in that baby-face, and in even the feigned look of harshness in the photos portrayed by the media, I could not help but see Ray Ray.

Over the years I have watched, listened, and even held my breath as he has experienced and agonized over how he is frequently perceived by strangers, Whites, other racial minorities, and law enforcement most of all. Disheartened, I watched as he, in an attempt to not appear threatening or intimidating, began to oddly contort his personality, appearance, and interactions in an attempt to not appear so "big" in the public eye. I even remember him being afraid to pursue the ball in soccer when he was a child because he was so fearful that he would hurt someone. For a time, rather than tackling his opponents on the football field he opted to just hold them.

I, on the other hand, have had the freedom to lose my cool without being perceived as a physical threat to society. How frustrating must it be to live small so that others can be big, so that others can feel safe? The thought alone leaves me feeling ostensibly bound and restricted, as if my arms are heavy, neck is tired, and knees have been bent for far too long. I imagine it is 
like the feeling that you get three hours into a tumultuous flight where a mandatory fasten seatbelt restriction has been placed on the passengers by the captain. Your joints begin to tingle, muscles tense, and bladder inconveniently announces that it is full. You can proceed to the lavatory and release yourself, but with great risk. Rather than chancing it, most will sit. They will sit with their frustration, bound greatness, and unexpressed hurt which has long since become rage; yes, eventually, they will come to pay the price for fear. The question becomes, will it quietly eat away at them until they can no longer take it, or will they resign to a position of learned helplessness and come to hardly notice the manner in which they are tightly restrained.

It sounds extreme, but the training that is built into being raised as an African American man is extensive and for the fortunate it often begins young. For years, as a young African American man your hair was to be short, brushed, and shaped up so as to avoid looking like a "pickaninny"4. For the short time that hair became accepted it was to always be well groomed, lest you be viewed as dirty. You can listen to your music, but with headphones and not too loud or someone might think you are a thug. You can wear your clothes, but certain garb is not appropriate for school. As a young African American male, you are told to stay late with your teachers so they know to take you seriously; otherwise you will be seen as an athlete rather than a student-athlete. You need to participate in school activities so that your peers and school staff know who you are and grow less threatened by and more comfortable with your presence. As a young African American male, you must smile and speak when you pass others, that way others will know you are kind. You are told not laugh or talk too loud. Heck, while you are at it you might as well touch your nose, hit the ground, and do a jig. Though some of these instructions are not exclusive to African American men, the consequences of their deviating from what many who are outside of the culture perceive as a strict upbringing can often be dire and mean the difference between life and death.

Many years ago I worked as a Youth Advocate at a not-for-profit community agency. I will never forget my work with one youth in particular. At the time, he had a child on the way but read at a very low reading level and was subsequently ill suited for most job opportunities, all but one in fact. The glitch was that all young men at this site had to cut their hair which meant that his dreads had to go. When his reality requires that he lose himself in order to provide for his family, he is given few choices. Though I would have loved to have been able to tell him to forget about the job, in good conscience, I could not. For this and all the many times that I felt led to instruct my brother or any of my youth to fit into the tiny box that society is much more comfortable with them living in, I am deeply sorry. I have concluded that I am likely to carry some stitch of guilt with me for the rest of my life on account of these actions. For the incredibly difficult position that I and all female African American guardians are put in when forced to decide between raising our young men to be who they are most comfortable being or encouraging them to present as some watered down rendition for society, I am angry. How do I decide which path to direct them down, which is the lesser of two evils?

Many spend a lifetime trying to convince themselves that the instances of racial discrimination that they experience, whether subtle or overt, took place on account of some other factor.

\footnotetext{
${ }^{4}$ Pickaninny refers to oft-depicted physical stereotypes of young African slave or African American children: bulging eyes, unkempt hair, red lips and wide mouth into which they stuffed large slices of watermelon. (Retrieved from http://www.urbandictionary.com/define.php?term=pickaninny)
} 
Whether the shooting was racially motivated or not, the circumstances surrounding the delayed arrest of Zimmerman are hard to rationalize any other way. When an arguably clear-cut case of racially motivated injustice takes place, the seemingly dormant but emotionally charged community cannot resist the opportunity to rally in support. This is especially true for those community members who have never had the chance to speak up on the injustices that they have personally endured. The thought being, "they gotta give us this one, there is no way that the lopsided scales of justice that consistently fall heavy on the color line can be ignored." I am not sure which is scarier, what will happen if Zimmerman is not convicted or what it will mean if he is.

\section{My Ground - Kidist M. Square}

The phrases "trust the system," "he is innocent until proven guilty," and "it is not about race," all sound like gibberish to me. I have tortured myself asking how many more killings, beatings and racist affronts do we as Black people have to face just to make it in this crazy seemingly "White" world. How many African American men must die on account of the assumption that they are all "suspicious?"

The Trayvon Martin murder is not a real surprise to me. For decades people have gotten away with killing Black boys; it seems it has become a way of living for some people. I guess "we the people" are supposed to believe and trust enough in a system that racially profiles and categorizes us, to say, "Zimmerman deserves a fair trial," and "it was self-defense." I am more than convinced that things would go differently if an adult Black man were to shoot and kill an innocent White kid based on assumptions. I would bet all my chips that many would not accept that the shooter was "innocent until proven guilty," or better yet it would be baffling that this White kid was suspicious based on his apparel.

The country's suspicions have resulted in many multi-million dollar incarceration facilities that disproportionately detain African Americans, millions of little Black boys and girls who continue to receive a subpar education, and millions of families who cannot afford proper health care due to their low incomes. African Americans are traumatized and the lack of simple respect from our own government seems to have a hold on us. Yet the U.S. government chooses to overlook the impact that the prior capturing, enslavement, and barbaric treatment of our people still has on us. Many White people ignore the impact that limited access to public rights, social liberties, and personal freedoms have had on African Americans, and then wonder why we are so behind. I am not sure how I can compete with people who choose to ignore my pain and suffering, with people who form their mouths to say, "I do not see color".

I feel numb, I feel no pain, and I feel no sympathy. It is like the country instantaneously warped back 200 years and we are back in a time period where African Americans were told to "be seen and not heard." Back when we were considered "the help." While we have the responsibility and honor to care for White people's children and cook their food, we are not respected enough to eat at the table or on a real plate for that matter. We are not even treated as second-class citizens. Instead we are classified and thrown into a category that falls between not good enough and suspicious. This is supposed to be the "Land of the Free," but I never quite understood the meaning of the phrase. 
Despite changing times, a reality of our history as African Americans is that some people will always feel justified to shoot and kill us on sight because they believe we are less than human, or more recently, "suspicious." We continue to live in a society where we, African Americans, must change who we are, how we dress, and how we speak. These things are all monitored and controlled to ensure that we do not scare off the White folk. Minus the whips and chains, in many ways we are still enslaved and still judged. .

Though I welcome the immigrants wanting and fighting to get into this country, I hesitate to promise equal opportunities and the American Dream. Despite having what feels like a whole society and generations of hate, racism and discrimination against people of color, many of us fight and struggle just to amount to something. I do not hate White people but they seem to hate me. At one point in time, I felt many White people assumed I was uneducated and uncivil for simply being Black. The lingering effect of this burden is a difficult obstacle to hurdle and many of my people will spend their lifetimes trying to overcome it. Fortunately, though there is work left to do, I am in the process of surpassing these hurdles.

Sometimes I am left wondering how we as Black people can adjust to and find our way out of this unhealthy lifestyle of suspicion. How long are we going to constantly sweep our problems under the rug and continuously trip over it; how long until someone falls hard enough to finally reveal the unruly pile and force us to dispose of it? I am a graduate student in a counseling program that asks us to address and put our personal biases on the table. Discussing racism, White privilege and the Trayvon Martin murder in my multicultural course was not the easiest. Looking at my classmates' White faces and blank stares as I rambled about the hurt, pain and hostility I felt towards them, and people that looked like them, made me more upset, uptight, and bitter. For 14 weeks we talked about race, and after each week I felt little hope, no power and minimal progress. As the $15^{\text {th }}$ week approached many of my White peers still did not get my point or purpose; the point that there is a power struggle in the United States and that race plays a role in determining almost everything.

Though I still struggled at the conclusion of the course, because I found the courage to speak up I did begin to feel a sense of relief. When I broke my silence it was as if the weight that my ancestors and I have carried for centuries was beginning to be lifted. Making a plan of action has helped me in my process of healing. Although I plan to continue to educate and inform those around me about White privilege, I will no longer point the finger at those who face me. I no longer place blame on my counterparts or spit out hate and evil against the White race. I have begun and am continuing to change. Change hate into hope, change fear into power and change weakness into strength. I am stronger now; so as I educate readers of all races about my story, I will in turn educate myself.

I am uncertain how we as Black people adjust to and find our way out of this unhealthy lifestyle of suspicion. Personally, I do not know how to tell Black boys that they must change their identity only to come up short in this frequently crooked society. I do not know the pain and worry a mother has when she sends her little boy out into the world every day. In what seems like a "White world", White people appear to be carefree. As an African American woman, I am always aware, cautious and on full alert. I cannot imagine the struggles of what it feels like to be a man of color or the mother of young Black men, but I do have my own story; the story of a Black woman and that in itself, speaks volumes. 


\section{Analysis of the Reflections}

This article includes four very personal and diverse reflections on the murder of Trayvon Martin. While there may be common themes across the reflections, it is important to note that each writer has her own individual voice. The thoughts and feelings expressed in each reflection, as well as how they are expressed, belong solely to that writer. The individual nature of each piece reflects each author's different writing styles, wording, and lived experiences.

\section{common Themes}

An analysis of our reflections results in the emergence of three consistent themes. The themes that cut across our reflections are indicative of not only our reactions, but also what we believe are the sentiments of many in the African American community in the wake of Trayvon Martin's murder. The three themes were: anger, frustration and raw emotions.

Anger. The authors all expressed anger in their reflections. The anger that was articulated focused on two issues. First, the authors expressed anger over the lack of humanity extended toward African Americans. The authors felt anger at how tenuous and fragile African American male life can be. For example, Jones stated "...it feels as if white men can kill Black boys and rape Black women of their identity and get away with it" and Square asked, "How many African American men must die on account of the assumption that they are all 'suspicious'?"

Second, the anger expressed by the authors was directed toward systematic issues including the justice system. For example, Roane stated, "...they (Sanford, Florida authorities) considered that the public would not question their decision to dismiss Trayvon's death as unworthy of further investigation". Bell wrote, "... when forced to decide between raising our young men to be who they are most comfortable being or encouraging them to present as some watered down rendition for society, I am angry".

Frustration. Frustration was another theme that emerged for all authors. The authors not only felt anger over the lack of response by the justice system, but also expressed frustration concerning the inequalities within the system. For example, Bell reflected this in a metaphor, "...they will sit with their frustration, bound greatness, and unexpressed hurt which has long since become rage; yes, eventually, they will come to pay the price for fear."

Raw emotions. The fourth theme reflects the raw emotions that were apparent in all four reflections. These raw emotions were a result of writing these reflections almost immediately following the heavy news coverage of Trayvon's murder, and in the midst of repeated discussions in our classes. Though sympathetic, our White classmates were unable to be truly empathic because they could not imagine what it must feel like to walk around day-to-day being on guard and hyper vigilant. Square recalled, "(I)ooking at their White faces and blank stares as I rambled about the hurt, pain and hostility I felt towards them and people that looked like them made me more upset, uptight, and bitter." As feelings were shared, entire classes were moved to tears and our classmates were forced to sit with their true emotions as well as their awareness of the injustices taking place in our country. 
The process of educating our classmates about the injustices encountered by African Americans in light of Trayvon's murder brought on a great deal of pain, hurt, anger, and frustration for the authors. Our souls were so deeply affected that our unfiltered emotions can be felt throughout our reflections. It was not for us, but for Trayvon and our loved ones that we allowed ourselves to dig deep into our systematically locked emotions. Our reflections are for our sons, brothers, husbands, partners, fathers, uncles, and the next generation of Black men in the hopes that they do not become the next Trayvon Martin.

\section{Where We Stand Today: Current Thoughts}

This article was prepared just weeks after the murder of Trayvon Martin. Now that over eight months have passed, we wanted to provide a brief update on our emotions and where we stand today.

Ricshawn Adkins Roane: While I wish I could say that my emotions have tempered, my heart still aches for the parents of all young children gone too soon and my fear for my own children still exists. However, I am buoyed by thoughts of social justice victories of the past and by the notion that readers who have stayed with these reflections to the end will be willing partners in future social justice struggles.

Tiffany Jones: I am no longer as angry as I was eight months ago when I first began to write this reflective piece. I spewed out my anger and disgust for privilege onto anyone who would listen. I was vulnerable and deeply saddened by the thought that one day when I will be blessed to carry a child of my own, my greatest struggle will be seeing him live until 25 . I was hurt that I developed anxiety surrounding checking in with my significant other because I was not sure if he too had become a slain victim. Every time it rains, I feel apprehensive about wearing a hood to protect my head. I make the very conscious decision of whether I am willing to take the risk of being shot as well in an effort to protect myself from the inclement weather beating at my face. I will forever be indebted to Trayvon Martin for being the face of social injustice and sparing the lives of those near to me.

Reston Bell: Months have passed and though the anger and disappointment remain, they are far better directed and hope has begun to creep back in. I was at a church service a few months back and the pastor reminded the congregation that our attitudes ought to reflect the fullness of our circumstance. Though things get bleak and long shadows are sometimes cast in our dark places, shadows can only be seen where a source of light is present. Trayvon Martin did not die in vain; in his death the complacent among us were reminded that although times have changed, equity in the pursuit of justice for ALL is still not a consistent reality. Similar to Hurricane Katrina, some tragedies come to push us out of our comfort zones and reveal our areas of weakness. Though this has been a difficult process and a hard loss to bear, it has served to help strengthen us where we are weak.

Kidist Square: I never imagined my raw feelings and thoughts would rise up in such a way that they could possibly be the make or break of my education, career and life. I have come a long way, and while my thoughts on this topic may not be the prettiest or the nicest, I now recognize that I am human and my anger is a part of that process. As a future educator, I 
wonder about the "ah ha" moments we have in life, at school, or at home: when we will feel them, where we will be when we do, and what we plan to do with the newfound outlook when it arrives. My moment actually came to me while writing this article. I feel the pain and ugliness of myself in this article, and while the issue at hand might have called for it, it is not me. It is a piece of me that had been suppressed and ignored. Thankfully, that is no longer me. No, I have not become one with Mother Nature or a sinless person; but unlike many I have unlocked the pain and anger. I faced it and have allowed my open mind and heart to continue to grow.

\section{Recommendations}

It is our sincere hope that readers walk away from this article having been informed or reminded of the turbulent climate in which young African American men are coming of age. We recognize that some of our reflections are raw but they are in keeping with the belief that it is only through transparent and sincere disclosure that others may come to understand and that we may come to find some sense of peace. Though we opted to share some of our deepest felt and most successfully hidden emotions, it was not our intent to offend or lose those who are trying to understand. Rather, our goal here was to candidly and honestly recreate the sentiment that many in the African American community carry on a daily basis. Though at times the burden becomes difficult to bear, we are hopeful and certain that there are concrete steps that we can all take to help lighten the load. What follows is a list of implications and recommendations for counseling and psychology trainees, educators, and practitioners to keep in mind as we all move forward in the field.

The following list of action steps can and should be taken whenever possible by those students, educators, and counselors that are in the field. However, prior to taking action there are a handful of critical tenets to which we must adhere: (a) We must each acknowledge the struggle that is unique to African Americans; (b) We must each acknowledge the painful historical roots of racism; and finally, (c) we must each acknowledge the harm that racism has, is, and will continue to inflict if we do not continue to engage in critical reflection, self-awareness, and honest dialogue.

\section{Training Programs/Educators}

- Competent Training. Training programs of ALL human service related disciplines need to do a better job of training White individuals to be aware of not only their privilege, but the harm that has been and continues to be inflicted upon many communities and groups because of stereotypes, profiling, and fear based assumptions. It is therefore essential that training programs facilitate honest open dialogue about issues of privilege, biases, prejudices, discrimination, and racism. Training programs must provide an opportunity for individuals to undergo genuine self-exploration of their values.

- Create New Experiences. We cannot change the past, but we can work on developing programs and opportunities that facilitate the development of positive experiences and interactions for individuals and systems that have historically had negative interactions with members of the African American Community.

- Support System. If there are opportunities for students to take peaceful stands and engage in personal self-expression through rallies, forums, demonstrations, 
or town hall sessions taking place in and around their university, educators should support them with their presence or by providing them with opportunities to share their experiences with their classmates.

\section{Practitioners}

- Empower. In discussing the concept of locus of control, Sue and Sue (2008) refer to internal control as "people's beliefs that reinforcements are contingent on their own actions and that they can shape their own fate" and external control as "people's beliefs that reinforcing events occur independently of their actions and that the future is determined more by chance and luck" (p. 294). A hallmark of an external locus of control is a sense of powerlessness over one's fate or over that of one's loved ones. Our hope is that our reflections will provide some context for why people of color may present with more of an external locus of control. Indeed, even if a client of color typically presents with an internal locus of control, the sense of powerlessness engendered by events like the murder of Trayvon Martin may challenge that orientation. Counselors and psychologists should be knowledgeable regarding the locus of control continuum and engage in activities that empower clients and communities where possible.

- Listen and Believe (McGoldrick, Giordano, \& Garcia-Preto, 2005). On behalf of clients of color, if we could ask for one thing from the predominantly White counseling profession, we would ask that they "listen and believe" our stories; that they open their heart and minds to truly hearing our experience and acknowledge our worldview as our reality. Before we can seek to educate others on racism, we as counselors must first learn to confront, see, and believe that it exists.

- Broach Race and Ethnicity. In the course of a traditional counseling relationship, the feelings of powerlessness we articulated above may never come to light. As a counselor, how do you approach the topic of race with your clients? Broaching, defined in Day-Vines et al. (2007) as "the counselor's ability to consider how sociopolitical factors such as race influence the client's counseling concerns" ( $p$. 401 ), is critical for counselors to truly assess the role of race and ethnicity in their clients' worldview.

- Create Safe Places. As mental health practitioners, we need to actively advocate and seek to create safe places where: Young African American men can safely disclose the emotions that they experience as a result of discrimination and can develop strategies for handling them. Young people of different backgrounds can safely engage in courageous conversation surrounding racial, gender, sexual orientation, religious, as well as any other form of discrimination or stereotyping that they have experienced and/or engaged in.

- Advocate. Develop community programs that seek to empower both community leaders and law enforcement officials to work through the history of discrimination and distrust.

- Courage to Confront Issues. It is important that counselors bring issues of racism and discrimination to the surface and discuss them; sweeping issues under the rug causes nothing but a pile of unwanted dirt that we will constantly trip over until it is revealed and cleared. 
- Self-Awareness. Understand how exploring race and racism will affect you as a counselor and psychologist. This involves delving deeply into one's self, and asking questions such as, "Why do I feel the way I am feeling".

In summary, we are counselors, psychologists, educators, activists, advocates, parents, and children. We hold the power to change the world and it starts with just one: one decision, one person, and one change at a time! We hope that our reflections have given readers a deeper understanding of the pain felt by the African American community. This pain is due not only to the murder of Trayvon Martin, but also the decades of racism continuously encountered by our community. We also hope that the reflections will propel readers to create and advocate for change and to speak out against racism.

You must be the change you wish to see in the world. - Mahatma Gandhi

Contact information:

Reston Bell

Department of Counseling and Development

Graduate School of Education

George Mason University

4400 University Drive, 1F5, Krug Hall 202, Fairfax, VA 22030-4444

Email: rbell7@masonlive.gmu.edu

\section{References}

Centers for Disease Control. (2004). Leading causes of death by age group, Black males United States, 2004. Atlanta, GA: U.S. Department of Health and Human Services, Centers for Disease Control and Prevention. Retrieved from http://www.cdc.gov/men/lcod/2004/04black.pdf

CNN Wire Staff (2012, April 11). Timeline of events in Trayvon Martin case. 3CNN. Retrieved from:http://www.cnn.com/2012/04/11/justice/florida-teenshootingtimeline/index.html?iid=article sidebar

Day-Vines, N. L., Wood, S. M., Grothaus, T., Craigen, L., Holman, A., Dotson-Blake, K., \& Douglass, M. J. (2007). Broaching the subjects of race, ethnicity, and culture during the counseling process. Journal of Counseling \& Development, 85, 401-409. doi: 10.1002/j.1556-6678.2007.tb00608.x

Hughes, L. (n.d.). I, too, sing America. Retrieved from http://www.poets.org/viewmedia.php/prmMID/15615 
Mahatma Gandhi. (n.d.). BrainyQuote.com. Retrieved from http://www.brainyquote.com/quotes/quotes/m/mahatmagan109075.html

McGoldrick, M., Giordano, J., \& Garcia-Preto, N. (2005). Overview: Ethnicity and family therapy. In McGoldrick, M., Giordano, J., \& Garcia-Preto, N. (Eds.), Ethnicity \& family therapy 3rd ed. (pp. 37). New York: The Guilford Press.

Sue, D. W., \& Sue, D. (2008). Counseling the culturally diverse: Theory and practice. Hoboken, New Jersey: John Wiley \& Sons, Inc.

The Florida Legislature. (2012). The 2012 Florida statutes: Chapter 776 Justifiable use of force. Retrieved from

http://www.leg.state.fl.us/statutes/index.cfm?App mode=Display Statute\&URL=07000799/0776/0776.html 